\title{
Pharmaceutico-analytical Standardization of Katupila Taila; An Ayurvedic Dosage Form from Ethnobotany: Securinega leucopyrus
}

\author{
Research Article
}

\author{
Samip Shah1*, Prashant Bedarkar², Shukla V J3, Patgiri B J4 ${ }^{4}$, Mehul Mehta ${ }^{5}$ \\ 1. PhD Scholar, 2. Associate Professor, 4. Professor and Head, \\ RasaShastra and Bhaishajya Kalpana Department, \\ 3. Head, Pharmaceutical Chemistry, I.P.G.T.\&R.A, \\ 5. Head, Quality Control Department, Indian Institute of Ayurvedic Pharmaceutical Sciences, \\ Gujarat Ayurved University, Jamnagar, Gujarat. India.
}

\begin{abstract}
Katupila - Securinega leucopyrus (willd) Muell. is ethnobotanic medicine, whose leaves are proven to exhibit wound healing property through in vitro, in vivo experimental studies and clinical study along with other properties like anti inflammatory, antioxidant etc. Present study was aimed to develop suitable Ayurvedic dosage form which can value add to ethnic practice and outcomes of recent studies on Katupila by utilizing probable potential of its alternate aria plant part; stem. Six batches of Katupila taila were prepared from decoction and bolus of stem of Katupila heated with Sesame oil in prescribed manner of Snehapaka as per Ayurvedic classics till Madhyam Snehapaka. Organoleptic, physicochemical evaluation, test parameters for evaluation of Snehakalpa as per Ayurvedic Pharmacopeia of India (API) were recorded in triplicate along with chromatographic pattern. Average $934.8 \mathrm{~g}$ (93.48\% yield) of Katupila Taila was obtained from batch size of, $1 l$ of Tila Taila with $212 \mathrm{~g}$ of Kalka dravya and $4 l$ of Kwatha of Katupila stem prepared over 3 days with $13 \mathrm{hrs}$ of total duration of actual heating. Mean specific gravity, refractive index, acid value, iodine value, saponification value and Bellier's turbidity temperature test (BTTT) value were $0.9179,1.4492 .908 \pm 0.0538,108.075 \pm 2.97,169.66 \pm 8.91$ and $19.6 \pm 0.3$ Mean \pm SD respectively. Adopted method of Snehapaka for preparation of Katupila Taila can be considered as standard. Observed organoleptic features, range of physicochemical parameters and chromatographic pattern as per API may be considered as analytical standard for Katupila Taila.
\end{abstract}

Key Words: Ethnobotany, Formulation development, Katupila taila, Katupila stem, Securinega leucopyrus, Snehakalpana.

\section{Introduction}

Ethnomedicine is the study of traditional or folklore medicine which is concerned with health, diseases and healing practices.(1) Katupila (Securinega leucopyrus) is not mentioned in any Ayurvedic classical text book, but in floras of some region it is recognized as very potent medicine.(2) Many researches are conducted on Katupila leaves in recent years which substantiate its Pharmacological as well as Clinical efficacy. Application of paste of Katupila leaves with Tila taila to patient's wound, exerts significant effect in wound healing.(3) But pharmaceutical, analytical \& pharmacological studies of Katupila stem is still remained a wide area of exploration. An effort is made to provide stable pharmaceutical dosage form which is suitable for the industrial application. Tila Taila

* Corresponding Author:

\section{Samip Shah}

$\mathrm{PhD}$ Scholar,

Rasa Shastra and Bhaishajya Kalpana Department,

I.P.G.T.\&R.A, Gujarat Ayurved University,

Jamnagar 361008, Gujarat, India.

Email Id: sam6453@gmail.com possesses wound healing activity internal as well as external.(4) Many Ayurveda dosage forms are unique in terms of their principles of formulation compounding, formulation design, mechanism of action etc. Most of the tests described in literature appear to be based on observations and seems to be subjective. It would be value addition to utilize contemporary methods of test parameters to monitor process control and assure their precision and assure repeatability and quality of derived dosage form. Standardization and development of reliable quality protocols are important especially in regard to formulations or practices of ethnobotanic origin or formulations developed from ethnobotanic practices to strengthen them, provide scientific base, maximize their therapeutic utility by increasing their chance to bring them to mainstream medical practice. (5) Uniqueness, potential of Ayurvedic dosage forms being easy to manufacture, economic processing, versatility to pharmaceutical operations in terms of therapeutic utility and safety (probably because of similar pharmaceutical operations in daily use and organic origin drugs, ingredients, base raw materials for preparation etc.) However, standardization of Katupila Taila is desirable for its greater recognition and acceptance. The standardization study of formulation never be achieved by one or two parameters and hence 
is preferable to achieve it in a multidisciplinary way. With this in mind, the study has been undertaken to develop pharmaceutical standardization with six batches of formulation Katupila Taila. Organoleptic characters, physicochemical parameters were done with six batches of Katupila Taila and Tila Taila (Sesame oil).

\section{Aim and objectives}

- To develop standard manufacturing procedure of Katupila Taila (KPT).

- To develop analytical profile of Katupila Taila (KPT).

\section{Materials and Methods}

Pharmaceutical Study

Collection and authentication of raw drugs

Katupila stem was collected at its fruiting stage from Nana Thavaria villege, near Vijarkhi dam, Jamnagar (Gujarat) in June month. (Plate 1 fig.a)

Katupila (Securinega leucopyrus [willd]

Muell.) was authenticated in Department of
Pharmacognosy, IPGT\&RA, Gujarat Ayurved University; bearing Herbarium Voucher's Specimen no. 6317. (Plate 1 fig.b)

Tila Taila (FSSAI grade) was procured from the pharmacy, Gujarat Ayurved University. Formulation was prepared in Department of Rasa shashtra \& Bhaishajya kalpana laboratory, I.P.G.T\& R.A, Jamnagar.

\section{Preparation of Katupila Kwatha}

Physical impurities from raw material were removed manually. Yavkuta of Katupila stem was prepared in pharmacy, Gujarat Ayurved University. Then it was soaked in water overnight for 15 hours. Next day it was subjected to heat over Mandagni to Madhyamagni $\left(80^{\circ} \mathrm{C}-100^{\circ} \mathrm{C}\right)$ until half part is reduced. Kwatha was filtered in warm condition through cotton cloth and stored in stainless steel vessel for further process. (Table no. 1) (Plate 1 fig.d,e,f).

Table 1: Observations of Six batches of Katupila Kwatha (KPK)

\begin{tabular}{|c|c|c|c|c|c|c|c|}
\hline Batches > & KPK 1 & KPK 2 & KPK 3 & KPK 4 & KPK 5 & KPK 6 & Mean \pm SD \\
\hline $\begin{array}{l}\text { Initial Qty. of Katupila stem } \\
\text { (gm) }\end{array}$ & 1000 & 1000 & 1000 & 1000 & 1000 & 1000 & 1000 \\
\hline Size of the Pieces (c.m) & $2.3-4.5$ & $2.3-4.5$ & $2.3-4.5$ & $2.3-4.5$ & $2.3-4.5$ & $2.3-4.5$ & $3.4 \pm 1.1$ \\
\hline Diameter of the Pieces $(\mathrm{cm})$ & $0.10-0.48$ & $0.10-0.48$ & $0.10-0.48$ & $0.10-0.48$ & $0.10-0.48$ & $0.10-0.48$ & $0.29 \pm 0.19$ \\
\hline Total Qty. of Water (ml) & 8000 & 8000 & 8000 & 8000 & 8000 & 8000 & 8000 \\
\hline Total Time for Soaking (h) & $15 \mathrm{Hrs}$ & $15 \mathrm{Hrs}$ & $15 \mathrm{Hrs}$ & $15 \mathrm{Hrs}$ & $15 \mathrm{Hrs}$ & $15 \mathrm{Hrs}$ & $15 \mathrm{Hrs}$ \\
\hline $\begin{array}{l}\text { Temperature (after One } \\
\text { hour) }\end{array}$ & $101^{0} \mathrm{C}$ & $100^{\circ} \mathrm{C}$ & $101.5^{0} \mathrm{C}$ & $101^{0} \mathrm{C}$ & $100^{\circ} \mathrm{C}$ & $101^{0} \mathrm{C}$ & $100.75 \pm 0.6$ \\
\hline Duration (min) & $150 \mathrm{~min}$ & $156 \mathrm{~min}$ & $165 \mathrm{~min}$ & $148 \mathrm{~min}$ & $148 \mathrm{~min}$ & $152 \mathrm{~min}$ & $\begin{array}{l}153.16 \pm \\
6.52\end{array}$ \\
\hline Obtained Kwatha (ml) & 4180 & 4260 & 4290 & 4410 & 4340 & 4210 & $\begin{array}{l}4281.66 \pm \\
84.71\end{array}$ \\
\hline Fresh Residue (gm) & 1870 & 1932 & 1867 & 1892 & 1951 & 1877 & $\begin{array}{l}1898.16 \pm \\
35.17\end{array}$ \\
\hline
\end{tabular}

\section{Preparation of Katupila Kalka}

Katupila Yavakuta was taken in grinder machine to prepare fine powder. Fine powder was triturated with water to convert in to paste form. Boluses of Kalka were kept in stainless steel vessel for further process. (Table no. 2) (Plate 1 fig.c).

Table.2: Results obtained during Six batches of Katupila Kalka

\begin{tabular}{|l|l|l|l|l|l|l|l|}
\hline Batch & I & II & III & IV & V & VI & Mean SD \\
\hline Weight of ingredients (g) & 167 & 167 & 167 & 167 & 167 & 167 & 167 \\
\hline Quantity of water used $(\mathbf{g})$ & 45 & 44 & 45 & 45 & 45 & 45 & $44.83 \pm 0.40$ \\
\hline Total weight of Kalka $(\mathbf{g})$ & 212 & 211 & 212 & 212 & 212 & 212 & $211.83 \pm 0.40$
\end{tabular}

\section{Preparation of Katupila Taila}

Tila Taila in the mentioned quantity was taken in a stainless-steel vessel and heated over mild flame $\left(100{ }^{\circ} \mathrm{C}\right.$ for $8 \mathrm{~min}$ ) till complete evaporation of moisture and then heating was stopped. After that boluses of Kalka were added to Tila Taila at $80^{\circ} \mathrm{C}$. After mixing of Kalka into Taila, the specified quantity of Katupila Kwatha was added and the mixture was heated over a mild to medium heat. Heating was continued maintaining the temperature in between $87^{\circ} \mathrm{C}$ to $101^{\circ} \mathrm{C}$ with intermittent stirring. The mixture was left undisturbed after discontinuation of direct heating till next heating and heating was given for 3 days. Mixture was stirred continuously to avoid the settling of solid contents and overheating due to possibility of settling down. Heating was continued on $3^{\text {rd }}$ day until Sneha Siddhi Lakshana were obtained. After obtaining desired Sneha Siddhi Lakshana, heating was discontinued and oil was filtered immediately through two folded cotton cloth in hot stage. After cooling, the prepared oil was kept in a vessel for a day for sedimentation allowed for settlement of suspended particles and filtered again and stored in labeled air tight bottle. (Table no: 3) (Plate 1 fig. $g$ to 1$)$. 
Table.3: Formulation composition of Katupila Taila

\begin{tabular}{|c|c|c|c|c|}
\hline No. & $\begin{array}{l}\text { Ingredie } \\
\text { nts }\end{array}$ & $\begin{array}{l}\text { Latin/ English } \\
\text { name }\end{array}$ & $\begin{array}{l}\text { Part } \\
\text { used }\end{array}$ & Quantity \\
\hline \multicolumn{5}{|c|}{ Kalka dravya } \\
\hline 0. & $\begin{array}{l}\text { Katupila } \\
\text { churna }\end{array}$ & $\begin{array}{l}\text { Securinega } \\
\text { leucopyrus Muell. }\end{array}$ & Stem & $167 \mathrm{gm}$ \\
\hline \multicolumn{5}{|c|}{ Sneha dravya } \\
\hline 2 & Til Taila & $\begin{array}{l}\text { Seasamum indicum } \\
\text { Linn. }\end{array}$ & $\begin{array}{l}\text { Seed } \\
\text { oil }\end{array}$ & $1000 \mathrm{gm}$ \\
\hline \multicolumn{5}{|c|}{ Drava dravya } \\
\hline 3 & $\begin{array}{l}\text { Katupila } \\
\text { Kwatha }\end{array}$ & $\begin{array}{l}\text { Securinega } \\
\text { leucopyrus Muell. }\end{array}$ & Stem & $4000 \mathrm{gm}$ \\
\hline
\end{tabular}

Plate No. 1

Pharmaceutical steps for preparation of Katupila Taila

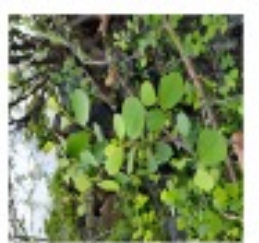

Fig 1

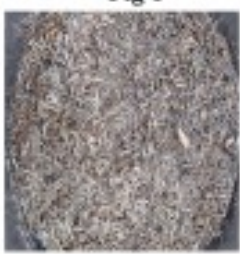

Fig 4

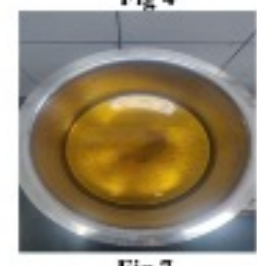

Fig 7

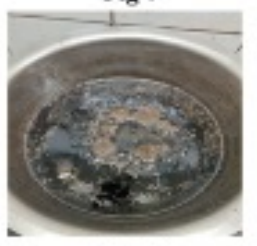

Fig 10

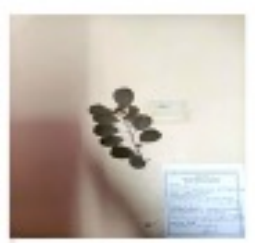

Fig 2

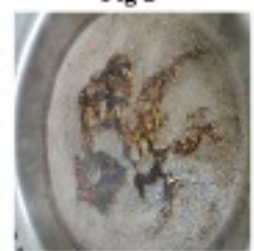

Fig 5

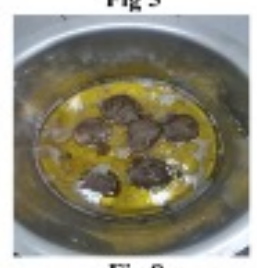

Fig 8

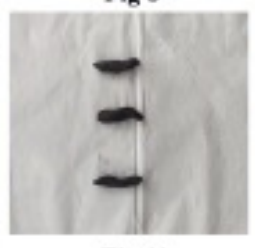

Fig 11

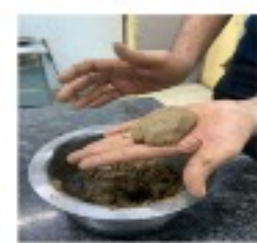

Fig 3

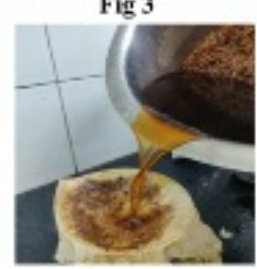

Fing 6

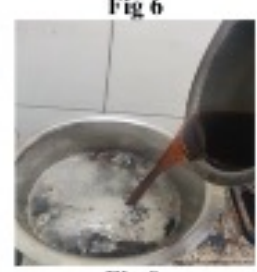

Fig 9

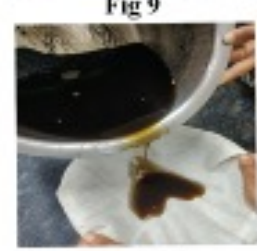

Fig 12
Pharmaceutical steps of Katupila Taila preparation

Fig. 1 : Plant of Katupila (Source)

Fig. 2 : Herbarium of Katupila (Securinega leucopyrus)

Fig. 3: Preparation of Kalka

Fig. 4: Soaking of Katupila stem yavakuta in water

Fig. 5: Preparation of Katupila Kwatha

Fig. 6: Filtration of Katupila Kwatha

Fig. 7: Heating of Tila Taila

Fig. 8: Addition of Katupila Kalka boluses

Fig. 9: Addition of Katupila Kwatha in mixture of kalka and Tila taila

Fig. 10: Phenodgam stage

Fig. 11: Mardanevartikotpatti

Fig. 12: Filtration of Katupila Taila

\section{Analytical Study}

Analytical evaluation of Katupila Kwatha (KPK) \& Katupila Taila (KPT) was carried out to develop standards for the reproducibility of product. The samples were analyzed on the basis of organoleptic characters. It includes sensory characters of drug i.e.
Sparsha (Consistency and texture), Rupa (Colour), Gandha (odor). Physicochemical parameters such as Specific gravity@25 C, Refractive Index, pH, Total Solid contents, Acid Value, Iodine Value, Saponification value, Bellier's turbidity temperature test() \& HPTLC were done for analysis of Katupila Taila at pharmaceutical Chemistry laboratory of I.P.G.T\& R.A, Jamnagar.

\section{High Performance Thin Layer Chromatography (HPTLC)}

$0.1 \mathrm{ml}$ of oil was taken and $1 \mathrm{ml}$ of hexane was added. The prepared solution was used for chromatography. Thereafter pre chromatographic derivatization was carried out. Alcoholic $\mathrm{KOH}$ (base) and thereby heated for 10-15 minutes in CAMAG TLC plate heater. Sample application was done using CAMAG linomat 5.

HPTLC of Katupila taila was carried out using solvent system Petroleum ether: Diethyl ether: Acetic acid $(70: 30: 2 \mathrm{v} / \mathrm{v})$. HPTLC study was performed for the normal phase separation of components of product.

Chromatographic study (HPTLC) was carried out under $254 \mathrm{~nm}$ and $366 \mathrm{~nm}$ to establish fingerprinting profile.

\section{Observations and Results}

Yield of dried Katupila stem from $17.170 \mathrm{~kg}$ quantity of fresh stems was $22.100 \mathrm{~kg}$ i.e. $77.69 \%$. While preparing Yavakuta of Katupila stem, $15.500 \mathrm{~kg}$ quantity of Yavakuta was obtained with $70.13 \%$. Total $2.090 \mathrm{~kg}(92.88 \%)$ of fine powder was derived from $2.250 \mathrm{~kg}$ of Yavkuta tailing 7.12\%. Mean diameter \& length of stem were $0.49 \pm 0.19 \mathrm{~cm} \& 3.4 \pm 1.1 \mathrm{~cm}$ respectively. Average weight of Kalka was $212 \mathrm{~g}$ after mixing with water. Prepared Kalka was light brown in color, having characteristic smell. During heating of Tila Taila (Sesame oil), foaming was observed which was probably due to moisture content of Taila. When temperature of oil reached at $75^{\circ} \mathrm{C}$ boluses of Kalka were added \& fried for around 10-12 minutes. The Kalka draya were added while discontinuation of heating to avoid overheating of Kalka dravya. After mixing of Kalka into Taila and four times of Katupila kwatha $(4000 \mathrm{ml})$ was added and again heating process was done with maintaining temperature in between $87^{\circ} \mathrm{C}$ to $101^{\circ} \mathrm{C}$ with occasional stirring. After 15 minutes of heating, bubbling was visible with peculiar odor of started with specific odor of Katupila. After half hour of heating, contents became dark brownish in color and upper layer of mixture was light brown in color with more viscuousness of mixture and frothing. After 1 hour of heating, light brown color of mixture was changed to dark brown having excessive frothing was observed during the process. The Taila was heated intermittently maintaining temperature in between 87 ${ }^{0} \mathrm{C}-101{ }^{\circ} \mathrm{C}$ for 3 days. On the third day, after $11 \mathrm{hrs}$ of heating process Phenodgama was observed. Kalka was examined at regular intervals. Mridu paka \& Madhyama Paka stages were observed at specific temperature which presented in Table no: 4. 
Consistency of Kalka became sticky to touch with no moisture and was able to make varti (Mardanevartikotpatti) and smooth in texture. At this stage of Madhyam Paka, Taila was filtered through cotton cloth without squeezing and in hot stage to get maximum yield of final product. On an average, total duration for Taila Paka and yield for each batch of Katupila Taila was observed to be approximately 13 hours and $934.8 \mathrm{ml}$ respectively after 3 days. (Table no: $5)$.

Table 4: Observation of six batches of Katupila Taila at different temperature

\begin{tabular}{l|l|l|l|} 
Sr. No & Observation & Temperature & Time \\
\hline 1 & Starting Temp. & $27^{0} \mathrm{C}$ & $0 \mathrm{~min}$ \\
\hline 2 & On addition of Kalka & $88^{\circ} \mathrm{C}$ & $21 \mathrm{~min}$ \\
3 & On addition of Kwatha & $84^{0} \mathrm{C}$ & $30 \mathrm{~min}$ \\
4 & During Phenodgama & $87^{\circ} \mathrm{C}$ & $11 \mathrm{hrs}$ \\
\hline 5 & During Mrudu paka & $89^{\circ} \mathrm{C}$ & $12 \mathrm{hrs}$ \\
6 & During Madhyam Paka & $91^{\circ} \mathrm{C}$ & $13 \mathrm{hrs}$ \\
\hline 7 & Duration between initiation of Mrudu paka \& end of Madhyam paka & $89^{\circ} \mathrm{C}$ & $72 \mathrm{~min}$ \\
\hline 8 & Duration (start from Mrudupaka) for appearance of Kalka Varti Pariksha & - & $75 \mathrm{~min}$ \\
\hline 9 & Duration (start from Mrudupaka) for disappearance of sound upon burning of wick. & - & $75 \mathrm{~min}$ \\
\hline 10 & Total duration of heating (Heating-cooling) & - & $13 \mathrm{Hrs}$ \\
\hline 11 & Total Time for the Process- (h) & - & $52 \mathrm{Hrs}$
\end{tabular}

Table 5: Results obtained during preparation of Katupila Taila (KPT)

\begin{tabular}{|l|l|l|l|l|l|l|}
\hline Parameters & KPT 1 & KPT 2 & KPT 3 & KPT 4 & KPT 5 & KPT 6 \\
\hline Quantity taken of Tila Taila $(\mathrm{g})$ & 1000 & 1000 & 1000 & 1000 & 1000 & 1000 \\
\hline Quantity obtained of Katupila Taila $(\mathrm{g})$ & 936 & 941 & 940 & 936 & 923 & 930 \\
\hline Total loss (g) & 64 & 59 & 60 & 61 & 77 & 70 \\
\hline Loss in (\%) & 6.4 & 5.9 & 6.0 & 6.1 & 7.7 & 7.0 \\
\hline Colour of Kalka & Dark & Dark & Dark & Dark & Dark & Dark \\
\hline Form of Kalka & Brown & Brown & Brown & Brown & Brown & Brown \\
\hline
\end{tabular}

\section{Specific observations}

Physico chemical parameters: physico chemical parameters of Katupila Kwatha are presented in Table no: 6

Table 6: showing physicochemical characteristics of Katupila Kwatha (KPK)

\begin{tabular}{|c|c|c|c|c|c|c|c|}
\hline Parameters & KPK 1 & KPK 2 & KPK 3 & KPK 4 & KPK 5 & KPK 6 & Mean SD \\
\hline Specific gravity & 0.9848 & 0.9920 & 0.9806 & 0.9880 & 0.9840 & 0.9838 & $0.9855 \pm 0.003$ \\
\hline Refractive index & 1.346 & 1.333 & 1.324 & 1.329 & 1.331 & 1.336 & $1.333 \pm 0.0074$ \\
\hline pH & 5.64 & 5.64 & 5.62 & 5.63 & 5.65 & 5.64 & $5.63 \pm 0.0103$ \\
\hline Total Solid Contents (\%w/v) & 0.2918 & 0.2818 & 0.2990 & 0.2927 & 0.2920 & 0.2924 & $0.2916 \pm 0.00$ \\
\hline
\end{tabular}

Organoleptic characters: The organoleptic characters of six samples of six batches of Katupila Taila are presented in Table no: 7.

Table 7: showing organolepic characters of Katupila Taila (KPT)

\begin{tabular}{l|l|l|l|l|l|l|} 
Organoleptic Characters & \multicolumn{1}{|c|}{ KPT 1 } & \multicolumn{1}{|c|}{ KPT 2 } & \multicolumn{1}{|c|}{ KPT 3 } & \multicolumn{1}{c|}{ KPT 4 } & \multicolumn{1}{c|}{ KPT 5 } & \multicolumn{1}{c}{ KPT 6 } \\
\hline Colour & Brown & Brown & Brown & Brown & Brown & Brown \\
\hline Smell & Characteristic & Characteristic & Characteristic & Characteristic & Characteristic & Characteristic \\
\hline Touch & Oily & Oily & Oily & Oily & Oily & Oily
\end{tabular}

Comparative physico chemical parameters of Tila Taila (Sesame oil) and Katupila Taila are presented in Table no: 8.

Table 8 : Showing physicochemical characteristics of Katupila Taila(KPT)

\begin{tabular}{|l|l|l|l|l|l|l|l|l|}
\hline Parameters & Tila Taila & KPTM 1 & KPTM 2 & KPTM 3 & KPTM 4 & KPTM 5 & KPTM 6 & Mean SD \\
\hline Specific gravity & 0.9103 & 0.9059 & 0.9109 & 0.9198 & 0.9063 & 0.9118 & 0.9123 & $0.9179 \pm 0.0050$ \\
\hline Refractive index & 1.386 & 1.459 & 1.434 & 1.456 & 1.449 & 1.453 & 1.443 & $1.449 \pm 0.009$ \\
\hline Acid value & 3.263 & 2.877 & 2.885 & 2.995 & 2.955 & 2.863 & 2.873 & $2.908 \pm 0.0538$ \\
\hline Iodine value & 109.860 & 108.012 & 106.032 & 103.726 & 112.186 & 108.345 & 110.153 & $108.075 \pm 2.9793$ \\
\hline Saponification value & 161.32 & 170.39 & 186.93 & 166.18 & 163.45 & 162.92 & 168.13 & $169.66 \pm 8.9132$ \\
\hline BTTT value & $21^{\circ} \mathrm{C}$ & $19.2^{\circ} \mathrm{C}$ & $19.5^{\circ} \mathrm{C}$ & $20.1^{\circ} \mathrm{C}$ & $19.5^{\circ} \mathrm{C}$ & $19.8^{\circ} \mathrm{C}$ & $19.6^{\circ} \mathrm{C}$ & $19.6^{\circ} \mathrm{C} \pm 0.3^{\circ} \mathrm{C}$ \\
\hline
\end{tabular}

HPTLC fingerprinting of Katupila Taila showed spots at $254 \mathrm{~nm}$, spots at $366 \mathrm{~nm}$ before spray. (Table no: 9) (Plate 2)

Table 9 : HPTLC fingerprinting of Katupila Taila

\begin{tabular}{l|l|l|l|l|}
\hline Solvent system & Wavelengths & No of Spots & Rf value & AUC (Area Under Curve) \\
\hline Petroleum ether (70) : Diethyl & $254 \mathrm{~nm}$ & 3 & $0.03,0.24,0.86$ & $14.09,11.98,73.93$ \\
\hline ether (30) : Acetic acid (2) & $366 \mathrm{~nm}$ & 2 & $0.03,0.89$ & $16.29,83.71$
\end{tabular}


Plate no 2

HPTLC of Katupila Taila at $254 \mathrm{~nm}$

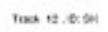

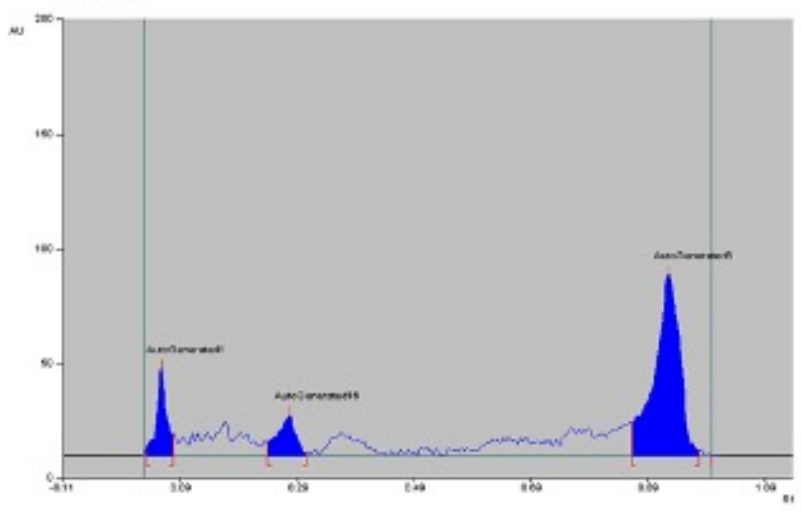

Plate no 3

HPTLC of Katupila Taila at $366 \mathrm{~nm}$

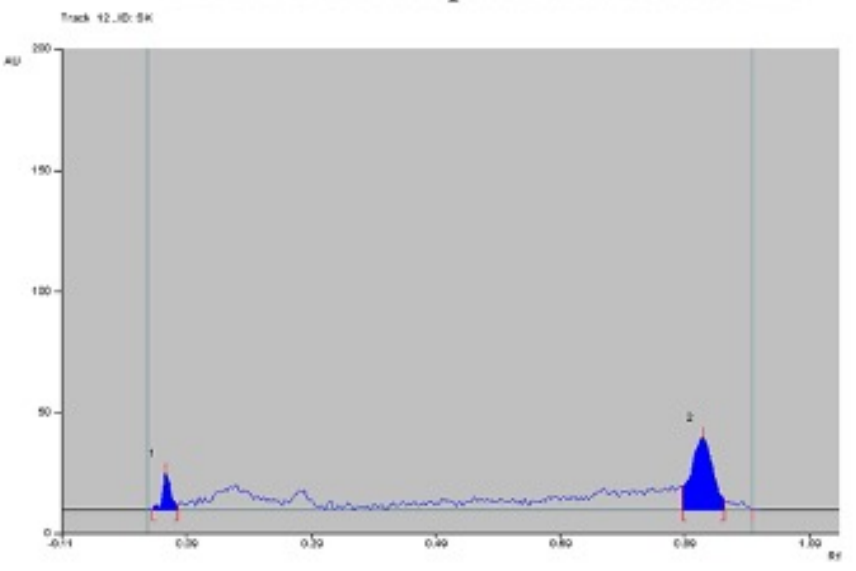

\section{Discussion}

In some previous researches application of Katupila leaf paste and sesame oil showed effective wound healing in Dushta Vrana (chronic wound).(7) Studies on wound healing effect of Tila Taila extract exhibits significant reduction in wound length in rats and it has potential to be developed into therapeutic agent for wound healing (8). Although Katupila leaves are widely used and several researches are done on leaf; stem may provide more biomass for medicament preparation as compared to leaves. Sneha kalpana is selected \& plant is processed with Tila Taila so fatty acids, lipogenic compounds \& plant basis complexes can be obtained.

As Snehapaka is carried out with Kwatha, quantity of Kalka was take as $1 / 6^{\text {th }}$ as that of Oil. During Snehapaka, temperature reached at $75^{\circ} \mathrm{C}$ after 12 minutes of demoisturization, boluses of Kalka Draya were added to protect the overheating of Kalka dravya. After 30 minutes \& 60 minutes of moderate heating, contents became light brownish \& dark brownish in color respectively which may be due to some physical/ chemical changes during heating process. On third day, after 11 hours of heating process (actual heating from begining) Phenodgama was observed, it may be due to presence of unsaturated fatty acids in Taila. When heated unsaturated fatty acids it was formed oxides which released foam. Taila was filtered in hot condition to get maximum yield. An average $6.51 \%$ loss was found during preparation of Katupila Taila (KPT) which may be due to more absorption of Taila in to Kalka and few losses may be due to sneha paka pariksha which may be due to highly polar nature of Kwatha and its constituents (phytochemicals) which is immiscible in fatty (polar) liquid media, thus there is need of time for reactions with to take place for formation of complexes of constituents of Kwatha with altered and probably continuously altering matrix of composition of sesame oil (trans fats, free fatty acids (FFA), volatile compounds, alteration in fatty acids composition like generation of saturated fats and continuous changes like oxidation, hydrolysis, saponification, etherification etc.) as a result of Snehapaka.(9)

As per tabled data (Table no:8), apart from RI and Saponification value, rest of the standards (rest of all analytical physico-chemical parameters) of Tila Taila chosen for present study are within limits for Sesame oil prescribed by regulatory authorities, which matches with API(10), BIS(11), CODEX(12), standards. This suggests need of development of inprocess standards and phytochemical marker studies of this formulation. Refractive index of samples i.e., Tila taila (1.386), finished product (1.449) were very different. Refraction of light in base oil compared to formulation may be due to addition of aqueous media, presence of suspended particulate matter, and change in concentration of extracted chemical moieties, addition /extraction of different chemical constituents in to Sesame oil or neo formation of different chemical constituents in to Sesame oil.(13) Specific gravity may also get altered (increased) due to some logically relevant reasons in final product (0.9179) as that of Tila taila (0.9103) which may be-formation of micelles due to heat treatment of oil with excess of aqueous media, suspension of solid particulate matter in to prepared Sneha, new generation of complexes with extracted constituents of formulation ingredients or their derivatives having comparatively more density than that of oil.(14) Inspite of known fact of increase in acid value after heat treatment of oils, comparatively lower Acid value of finished product (2.908) as compared with Tila taila (3.263) suggests formation of complexes of generated free fatty acids (FFA) and trans fatty acids (TFA) with phytoconstituents of Drug Katupila. More Saponification value in finished product (169.66) as that of Tila taila (161.32) may suggests formation of shorter chain fatty acids, with lower molecular weight and thus supporting fast and better absorption of generated phytoconstitution of oil.(15) Iodine value is a measure of the amount of unsaturation (number of double bonds) in a fat.(16) Increased Iodine value observed in Katupila Taila (108.075) as that of Tila taila (109.86) due to increased rate of oxidation during Sneha paka. Present study has incorporated maximum numbers of parameters of standardization of Sneha Kalpana advocated by pharmacopeia and evaluated by maximum number of research studies where to propose product standards of Katupila Taila. Present formulation may be 
modified to conventional dosage form like gel, cream, emulsion, etc. to provide Hydration of skin, increase in duration of contact of medicament at affected area and ease in cleansing of residual medicament during daily dressing.

\section{Conclusion}

Adopted method of Snehapaka for preparation of Katupila Taila can be considered as standard. Average 934.8 g (93.48\% yield) of Katupila Taila was obtained from batch size of, 1 l of Tila Taila with $212 \mathrm{~g}$ of Kalka dravya and $4 l$ of kwatha of Katupila stem prepared over 3 days with 13 hrs of total duration of actual heating. The changes in physicochemical parameters as that of Tila taila (Sesame oil) can be merely correlated to effect of heating, suggesting collective effect of formulation ingredients and pharmaceutical processing of Snehapaka.

\section{References}

1. Andrea P, Lisa LP \& Ina V. Journal of Ethnobiology and Ethnomedicine, volume 1, Article number: 1 (2005)

2. Dudhamal TS et al. A Wonderful Medicinal Plant: Securinega Leucopyrus (Willd) Muell- A Brief Review, International Journal of Science Inventions Today, 2016, 5(6), 472-484.

3. Ajmeer AS, Dudhamal TS, Gupta SK, Mahanta VD, Topical application of Katupila (Securinega leucopyrus) in Dushta Vrana (chronic wound) showing excellent healing effect: A case study, AYU, 2014; 35(2): 175178.

4. Kotade K, Mohammed A. Wound healing activity of Sesamum indicum $\mathrm{L}$ seed and oil in rats, Indian Journal of Experimental Biology, V1.46 November 2008, pp. 777-782.

5. Anantanarayana DB. Proceeding of International Congress on Ayuerveda, 28-30th January 2002, P.67.

6. DGHS, Directorate General of Health Services, Manual of methods of analysis of foods (Oil \& Fats) Food Safety and Standard authority of India
(FSSAI), Ministry of health and family welfare, Government of India, New delhi, 2012

7. Ajmeer AS, Dudhamal TS, Gupta SK, Mahanta VD, Topical application of Katupila (Securinega leucopyrus) in Dushta Vrana (chronic wound) showing excellent healing effect: A case study, AYU, 2014; 35(2): 175178

8. Mohammad RS, Javad AZ, Alireza S, Evaluation of the Wound Healing Activity of Sesame Oil Extract in Rats, World Journal of Medical Sciences , 2014, 9 (2): 74-78,

9. Sweta K, Baghel DS. A progressive pharmaceutical review on Sneha Kalpana, International Journal of Green Pharmacy,2018, 12 (1), 515-524.

10. The Ayurvedic Pharmacopoeia of India, PART I, Volume VI, First edition, Ministry of AYUSH, Government of India, New Delhi, 2007; monograph-98, Appendix-3, (3.10), P.220.

11. Indian standard specification for mustard oil, $2^{\text {nd }}$ revision, $6^{\text {th }}$ reprint, august 2007 , incorporating amendment no 1 and including amendment nos.2, 3, $4,5 \& 6$, Bureau of Indian standards, new delhi, IS:546-1975.

12. Issued by the Secretariat of the Joint FAO/WHO Food Standards Programme, FAO, Rome, 2nd edition, revised, food and agriculture organization of the united nations world health organization Rome, 2001, ISSN 0259-2916.

13. The Ayurvedic Pharmacopoeia of India, PART II (Formulation), Volume I, First edition, Ministry of AYUSH, Government of India, New Delhi, 2007; Appendix-3,(3.1),P.63.

14. Anonymous. In: Government of India, Ministry of Health and Family Welfare, DepKPTment of Ayurveda, Yoga and Naturopathy, Unani, Siddha and Homeopathy,editors. Ayurvedic Pharmacopoeia of India. PKPT I, Vol. IV. New Delhi.

15. Kasture AV. Pharmaceutical Analysis. Vol I, Nirali Prakashana, Pune, India, 13th edition, reprint 2009.P.11.2-11.3

16. The Ayurvedic Pharmacopoeia of India, PART II (Formulation), Volume I, First edition, Ministry of AYUSH, Government of India, New Delhi, 2007; Appendix-3, (3.11), P.74. 